\title{
Challenges and Opportunities of Homegrown Ways of Peace Building: The Case of Gada System in Borana Community of Southern Ethiopia
}

\author{
Assefa Tasgara \\ Department of Civics and Ethical Studies, Faculty of Social Science and Humanities, Mettu University, Mettu, Ethiopia \\ Email address: \\ asefatasgara@gmail.com
}

To cite this article:

Assefa Tasgara. Challenges and Opportunities of Homegrown Ways of Peace Building: The Case of Gada System in Borana Community of Southern Ethiopia. International Journal of Systems Science and Applied Mathematics. Vol. 6, No. 1, 2021, pp. 9-21. doi: $10.11648 /$ j.ijssam.20210601.12

Received: December 21, 2020; Accepted: January 21, 2021; Published: March 10, 2021

\begin{abstract}
This study is concerned with challenges and opportunity of gada system in peacebuilding among Borana Oromo community of south Ethiopia. The objective of this paper was to assess the challenges and opportunities of the homegrown (gada system) in peacebuilding in Borana Oromo community. To achieve the objectives, a qualitative case study of research design was implemented. Members of gada council, gada leaders who are active in peacebuilding, concerned officials from Oromia and Borana culture and tourism office of government structure, knowledgeable elders of the Borana Oromo community were purposively selected as a sample of the study. Accordingly, in-depth interviews, key informant interviews, and focus group discussions were conducted. Data obtained by interviews and focus group discussion were analyzed and interpreted by applying relevant approaches to qualitative research. The findings show that there are challenges and opportunities in the practice of Gada system in peacebuilding. The politicization of gada leaders, religion, lack of budget for gada institution, low knowledge of gada systems are challenges of gada system in peacebuilding. On the other side, the gada system has the opportunity to maintain peace and bring peace and stability due to its nature that promotes democratic cultures and principles as its core values. In general, the study concludes that an effort of peacebuilding by gada system is effective to some extent requiring more actions to be done. The community is peacefully asking their question as compared to the past four years which is more violent without destruction of resources currently but this does not mean it brought a complete or lasting peace among the group rather show the system has its own contribution in building peace in the Borana zone.
\end{abstract}

Keywords: Gada, Gada System, Peacebuilding, Politicization

\section{Introduction}

Every society has their own ways of handling disagreements and achieving resolution of differences regardless of their location in time and space of living. Gulliver (20) states that every society has its own devices of management conflicts including violent conflicts. Ethiopia is a country which has its own dispute settlement mechanisms in which the traditional ideas of democracies are inculcated. This homegrown method of handling dispute and any kind of conflict should get attention by researchers and academicians because they actually have long experiences in democratic cultural practices that mean indigenous peoples of the world. Academia has so far failed in effectively studying political cultures of indigenous peoples either strongly or judgmentally. Therefore, it is important to exclusively deals with indigenous mechanisms peace building in given society rather than following western viewpoints that may not consider the culture of domestic community

According to Murithi [30] examples of African traditional conflict transformation and peacebuilding can be haggard from gacaca courts in Rwanda, The kotgla in Botswana, Mato oput in Northern Uganda, bashingantahe in Burundi, gada Oromo in Ethiopia and ukuzidla in South Africa are some of them.

Ethiopia has been using traditional mechanisms of conflict resolution for centuries. The institutions of Gada among the Oromo, Joburas of Agnuak and the Shimagelle by the 
Amhara are among others. It is important to look at the interesting system among the Oromo society-the Gada system which directs power-sharing transfer that is referred to as democratic system by many scholars [36].

In the countries, like Ethiopia peoples' traditional values of Resolving conflict including protest have never been considered as crucial issues during its political, economic and social transition in the past. Gada Oromo is developed from the Oromo traditional belief, history, and cultures. It can be argued that some of them have achieved to create stable institutions with a mechanism of conflict prevention and resolution such as Oromo Gada system [17].

Gada frontrunners of the Borana Oromo of southern Ethiopia require enforcement mechanisms to resolve social, economic and political problems by serving as a energetic connection between the government and the people. With admiration to the security problem facing the country, gada leaders proposed recommendations advanced to the government were not observed in their entirety. The people have been protesting, simply manner their grievances, but, the decision of the government were only to use military force way of resolving the problem [31].

Zelalem (34) described the role of home-grown knowledge system like Gada system in his article entitled "Old Wine in New Bottle: Bridging the Peripheral Gada Rule to the Mainstream Constitutional Order of the 21st Century Ethiopia". His article responds to the search of the alternative solution to flat race of democratization process in Ethiopia through home-grown knowledge of governance, namely the Gada system.

Regarding Gada challenges and prospects in addressing the political instability in Oromia regional state which is at highest stage currently because of the outbreak of protests in the different areas of the Oromia regional states in general and Borana zone in particular is still there are a shortage of literature.

Therefore, the present study aimed at addressing this missing gap. It, therefore, examines aspects of peace building by gada system among Borana Oromo communities. The study explores the challenges and opportunities of gada institutions and practices of dealing with protests with special emphasis on the case of Borana Oromo protest in Oromia regional state. Particularly at this instant in time when most of the people desire for peace, but when the up-to-date devices of protecting peace do not give the impression to meet the needs of people, it is domineering to discover the roots that peace has in the traditional values of original societies [24]. In this light, this paper explores gada as a system of peace means for the Oromo both at the individual and societal levels, what goal it has for them, challenges and opportunities of gada in peacebuilding/making, and the mechanisms by which the Oromo make restore, keep and promote peace. For this reason, it would be appropriate and obligatory to identify the major challenges and achievements of Gada offices and search a remedy to create a sustainable peace for Oromo peoples.

\section{Approaches to Peace Building}

\subsection{Community Based (Traditional) Approaches to Peace Building}

Traditional approaches to peace building seek to authorize local public groups and institutions through a process that underlines inclusive participation and management. The basic premise for demand-led approaches is that local communities are better placed to detect their communal needs and the actions necessary to meet them [23]

This Traditional approaches to peace building grasps that customary headship has exclusive features and capacity to build democracy from below. Precisely, community based approach does not consider traditional institutions of governance as a hazard to democracy or human rights but then again as well-matched, in code, with modern governance. Moreover, they consider it as a legitimate organ and valid mode of governance and it facilitates for consensual democracy [34].

Traditional indigenous societies by their very nature tend to be communal, collective, and more prone to foster an atmosphere of peaceful co-existence. The application of traditional customs and values in reconciliation efforts may result in a more communal grassroots involvement and thereby contribute substantially to the eradication of the root causes of the conflict and to holistic reconciliation [34]

Given the highly localized or regionalized character of many of today's violent conflicts in the global south, there also is a high demand for conflict transformation mechanisms that are particularly effective at that local/regional level. Only if sustainable solutions can be achieved in the local context can it be expected that solutions on a larger national or transnational scale also can be achieved? Experience shows that solutions only 'at the top' are not sustainable if they are not based on solutions 'at the bottom'. And it is at the bottom that traditional approaches to conflict transformation are particularly effective. However, experience also shows that traditional approaches can take effect from the local through the regional to the national level and thus contribute to solutions in the sphere of state politics. Political solutions at the national level again can reinforce solutions at the local level. The Bougainville peace process is a good example of such mutual reinforcement of peacebuilding at the local and the national level under the inclusion of traditional approaches [9]. In brief, 'the bottom-up approach' involved a process of first attaining discussions and agreements to end the fighting at local peace conferences, by bringing together contiguous and symbiotic sub-clans, guided by the elders of each sub-clan. These conferences not only dealt with issues of immediate concern at local levels but also served to place responsibility for inter clan fighting on the shoulders of local leaders and helped to identify the persons who were considered to be right representatives of those clans' concerns [26].

In Africa, many normal conflict resolution devices have been developed and employed by the society since ancient time. Hence, the accustomed conflict resolution instruments in Africa have played and still playing a significant role in 
resolving conflicts of various degree and thereby maintain the peace of the society. For instance, Gacaca in Rwanda is a traditional mechanism of conflict resolution that attempts to address trauma and post-conflict reconstruction needs of that country's post-1994 genocide. The government of post-conflict Rwanda enacted the Gacaca Law to give indigenous courts the mandate to deal with cases of the genocide [25].

Oromo Gada system is one of African's extended operative traditional institutions that has been affecting all aspects of Oromo life (social, political, economic, cultural and ritual lives) for centuries. It mixes different social, political, economic and cultural commitments among the Oromo people. It also maintains Oromo people's identity, culture, unity, and egalitarianism. As part of Africa, different ethnic groups in Ethiopia have traditional and customary institutions of conflict resolution mechanisms which are inimitable to their own culture [3]. Similarly, the Oromo, being the largest ethnic group of Ethiopia, have had a variety of customary institutions of conflict resolution mechanisms. Many researchers who studied the Oromo's customary institutions of conflict resolution identified that jaarsummaa (council of elders), Gada System (Oromo socio-political organization), qaalluu (religious institution), siinqee (ritual stick used by women), gumaa (ritual of purification after homicide) and ilaa fi ilaamee (negotiation) are the well-known mechanisms, among many other mechanisms, that the Oromo use to deal with conflict. They further clarify that the Oromo not only use these mechanisms to deal with the conflict among themselves but also with the people living in their neighborhoods. These customary institutions have been serving for resolving conflicts for a long time, and are still continuing to function parallel with the formal structures [18].

The Gada system of governance incorporates indigenous worldview, an indigenous method of transfer of knowledge and peacemaking. Even after being incorporated into Ethiopian Empire, the Borana have managed to retain their ancient Gada socio-political system. The home-grown governance system with its establishments has continued to work well. The Borana have home-grown ways of managing the scarce resources and means of coping with harsh climatic conditions. They have an effective regulatory system for the use of common range resources like wells and pasture. They have their own indigenous ways of resolving disputes [39]

On the whole, the Borana aadaa seera refers to the totality of unwritten laws, norms, and ethical values, all of which are rooted in the Gada system. It is this totality of unwritten laws, norms, and values embedded in the Gada system in Borana which serves as a tool for determining right from wrong and advise measures to be taken in cases of violation of these rules. Oromo consider their laws to be the strongest instrument for the safeguarding and maintenance of Nagaa /peace [27].

Like many African societies, this approach to settlement of disputes is guided by this holistic and broader concept of peace which goes far beyond the settlement of disputes and extends to and embraces harmony with nature. In Oromo life, "peace is a pervasive and sustained concern" [27]. Among the
Borana everyday greetings constitute a form of preaching peace, for this reason, "a sustained feud between groups or individuals is unacceptable" [29]. For the Oromo, failure to resolve a conflict will lead to the breaking of the social and religious harmony that is Nagaa Oromoo, the peace of Oromo. In order to sustain their social harmony, the Oromo resolve conflicts without any delay [40]

In Borana Oromo communities, peace-building takes the form of elders from two neighboring clans playing an important part in defusing tensions and conflicts, which usually revolve around the control of grazing land or water. The understanding and experience of the elders are manifested in clear and well-articulated procedures for conflict resolution in which all the parties to the conflict are given the chance to express their views. On the other hand, the elders were vested with cultural authority to act as arbiters and even give judgment on the rights and wrongs of a disagreement submitted to them for resolution and then suggest a settlement, although they may have no power of physical force by which to enforce them. But often the pressures of culture guarantee obedience [11].

\subsection{Exogenous or Modern Approaches to Peace Building}

Traditional conflict transformation like Gada system of Oromo will scarcely be found in reality today. Native societies everywhere in the world have come under outside influences; they have not been left unchanged by the powers of originally European capitalist expansion, colonialism, imperialism, evangelism, and globalization. In real life, therefore, there are no clear-cut boundaries between the realm of the exogenous "modern" and the endogenous "traditional", rather there are processes of assimilation, articulation, transformation and/or adoption in the context of the global/exogenous-local/ indigenous interface. Nevertheless, it is worthwhile to base the argument on an ideal type of traditional, customary or local conflict transformation in the context of indigenous cultures and customs in order to elaborate as precisely as possible the specifics of certain approaches and institutions that do not belong to the realm of conventional modern institutions institutions that originated in the western world and were imported to and imposed upon indigenous societies in the global south [41].

At the top level we find what we might call the "top-down" approach to peacebuilding which can be characterized by, First, the people who emerge as peacemakers, often seen as intermediaries or mediators, are eminent figures who themselves possess a public profile, Second, the goal is to achieve a negotiated settlement between the principal high-level leaders in the conflict, Third, the peacebuilding approach at this level is often focused on achieving a cease-fire or a cessation of hostilities as a first step that will lead to subsequent steps involving broader political and substantive negotiations, which in turn will culminate in an agreement creating the mechanisms for a political transition from war to peace [26].

It goes with a liberal peace theory has provided an overarching rationale for international support to local actors 
by considering energetic civil society as an essential component of liberal democracies [33]. Neo-liberal Approach or Democratic Pragmatism School seriously opposes the old-fashioned governance system like the Gada system. They strongly argue that homegrown governance system like Gada principles is inherently imperfect and they cast doubt as to their compatibility with democratic values and fundamental human rights principles. These theorists (neo-liberalists) supporter prioritize individual rights rather than group rights. Additionally, the claim that the principles of democracy demand state nations that ensures access to democracy as a commodity to which all humans are entitled [21]

\section{Role of Culture in Peace Building}

As an Afrocentric worldview that sees an African culture as the center of African life, Oromummaa roots its visualization on Oromo popular democracy, an institution that existed before American democracy. There are numerous aspects of Oromo culture that have been important tools in maintaining their cultural identity. The one that plays most prominently in most academic discussions of the Oromo is the gada system which inaugurates aspects of Oromo religion, systematizes the structure of their society, and delivers a sense of time. Oromo religion has remained a strong aspect of Oromo culture regardless of the religious belief system held by the individuals or groups; whether practicing Christianity, Islam, or Oromo religion cultural elements of the Oromo religious system have continued consistent [37]

The principle of "African solutions to African problems" requires in-depth investigation and understanding of home-grown African culture (gada system of Oromo), values, norms and traditions [43]. Where peace-building is based on peripheral burdens aimed at merely securing the late Westphalian state and other elements of neoliberal internationalism, the moment the foreign actors (UN, external NGOs, etc.) withdraw, people who did not interact mutually with regards to political and economic reconstruction, or collectively define their postwar relationships will have to confront key issues [10]

The Oromo people have a separate culture and language of their own. That the Oromo culture and the symbols of democratic Gada democratic government and other institutions have continuously bore the last 105 years of continuous open and secret war by foreign forces is a remarkable testimony to the resolution of the Oromo cultural identity and democratic heritage [37]

Traditional cultures like gada institution are often characterized by methods embedded in ethnic wisdom for effectively resolving conflicts. However, the influence of westernization and external burdens may lead to their decease in practice. There is often a psychological and/or cultural dimension to the entire process of peace-building for human security oriented knowledge, ideas and norms should be the focus. The constant habitualization of positive intersubjective activities results in the institutionalization of shared goals, understandings, and a common destiny. For instance, the promotion of reconciliation and accountability in Rwanda and Mozambique through "gacaca" and traditional healing rituals in Mozambique respectively are a small example of this process [10].

The traditions, customs, and norms of a particular community played a pivotal role in conflict resolution. Traditions, customs, and norms were highly valued and adhered to by the members of the community. Disregard of some of these beliefs could attract the wrath of the gods, ridicule and reprimand from members of the society hence ensuring that persons shunned conflict-causing conduct [28].

Culture and leadership are highly integrated ones in Borana people"s worldview. Every action of men in the mainstream of the Gada system (Ilman korma), specifically those of Abba Gadaa men, are viewed and evaluated through the lens of the belief system. The decisions they make, their personal and group behaviors, their performances as leaders, interactions with others, and their activities, in general, should reflect the culture. They should reflect the culture of the community in any of their behaviors. They should speak and act truth of Waaqa. They should act in spiritual wholesomeness in their Gada performances [22].

\section{Research Design and Methodology}

In order to attain the intended objectives of the study, the researcher employed a qualitative approach. Qualitative approach was preferred due to its all-inclusive nature in analyzing the whole system of gada rather than simply in its one component. According to Creswell [13] the qualitative method enables to properly investigate and understand a social or human problem.

Hence, the data collected from the field using an in-depth interview, focus group discussion and observation is analyzed from the emic opinion of view. Secondary data sources from different books, journals, articles, and documented video are analyzed and presented.

\subsection{Participants of the Study}

Participants of the study include elders, local officials, Abba gadas and members of Gada Council (adula) in the area. Elders were selected bearing in mind their roles in the community, their ability to make peace in a society and the abbaa raagaa (oral historians) teach the sons argaadhageettii (eyewitness accounts and oral traditions) about history, laws, rituals, time reckoning, cosmology, myth, rules of conduct as well as the function and importance of the Gada System.

I have focused on Oromia and Borana culture and tourism office in selecting local officials for an in-depth interview. In addition, Abba gadas were selected because gada leaders of the Oromo have been working to resolve social, economic and political problems by serving as a vital link between the government and the people and they proposed recommendations forwarded to the government to resolve the political crisis in Oromia 


\subsection{Sampling Techniques and Procedures}

The selection of key informants from the Borana Oromo community has been carried out based on purposive sampling techniques. Purposive-sampling technique in which respondents were selected on the basis of certain predefined purposes employed as a tool to select the informants. The rationale is, the researcher could find and discern individuals with knowledge and experience about the study, for instance, gada leaders who are active in peacebuilding, concerned officials from Oromia culture and tourism office of government structure.

With this regard, the abba Gadas, gada councils and local officials that are closely involved in the process were selected for a particular purpose already in mind. However, that is to find and identify individuals with knowledge and experience about the topic under study.

In fact, selection of informants was conducted with the help of a research assistant from Borana culture and tourism office. In such a way, the researcher was able to get the people who have life experience and knowledge about the peacebuilding processes from Oromo elders. Accordingly, the present researcher selected the Oromo elders who have eyewitness account (oral historians) participating in peacebuilding through principles of Gada system.

\subsection{Data Collecting Instruments}

\subsubsection{In-depth Interview}

In-depth interviewing is a qualitative research technique that involves conducting intensive individual interviews with a small number of respondents to explore their perspectives on a particular idea, program, or situation. For example, we might ask participants, staff, and others associated with a program about their experiences and expectations related to the program, the thoughts they have concerning program operations, processes, and outcomes, and about any changes they perceive in themselves as a result of their involvement in the program (Boyce, C., \& Neale, P. 2006).

In order to get supplementary information for the study; in-depth interviews were carried out with individuals of different backgrounds and careers. Such interviews were conducted with persons in concerned government offices, Borana elders, and members of gada councils including Abba gada. The researcher chose two Borana Oromo elders and four from members of Borana Oromo gada councils as well as three government officials with the total of nine people purposively from Borana. The reason why the researcher selected members of Gada councils and Borana Oromo elders is that he thinks informants are responsible persons in the peacebuilding process in Borana zone. By considering the resource available and time schedule to conduct the study, informants' number was limited to Oromo elders and Abba Gada's because as the number increases the data might be bulky. The researcher assistants guided me and asked politely the respondents to give me the necessary information about the study at hand. In addition, the research assistants also made my questions clear to the respondents because even if I asked them in Afaan Oromo my accent was difficult in some cases to be understood by them.

\subsubsection{Key Informant Interview}

By preparing semi structured interviews, the key informants who are experts among oromia and Borana zone culture and tourism officials' members were interviewed. The main language of the interview was the Oromo Language (Afaan Oromo) my mother tongue. Then, I translated the transcribed data precisely to the English language. For this purpose, I selected four individuals using purposive sampling. I developed some criteria to select the key informants. Accordingly, all of the key informants have a first degree and above, they have high official positions and those who have background knowledge and deep experience on the Gada system of Oromo was taken into consideration in selecting them.

\subsubsection{Focus Group Discussion}

Conducting focus group discussions was undertaken because it is important to understand and identify the key concepts and issues that are critical in conducting the research. Besides, FGD helps in identifying key informants and other knowledgeable resource persons. With this in mind, three group Discussions were organized in Arbora, Konnitu and Hawwattu areas of Borana zone comprising six individuals for each focus group discussions. This was conducted during my data collection which took place one month observation in fields. After ensuring the confidentiality of the discussion and introduced himself, the researcher told the members to introduce themselves to each other.

To FGD purpose, I selected 7 basic questions from the list of questions prepared to guide the discussion. The same questions were administered to meet the prime aim of cross-checking the data. The homogeneity of the participants maintained by the plan, but, not by default. Fortunately, all the participants of FGD were members of gada councils who have a good experience in the peace process of the area.

I learned that some individuals were more knowledgeable than others do and they tended to take more time to talk. Hence, in order to give equal chance for participation, I arranged an in-depth interview for such individuals. Moreover, most of the participants were unable to explain or reason out their practices in the system during focus group discussions. Therefore, the alternative available at the time was to select the main points of discussion out of focus group discussion guidelines for an in-depth interview. Then, an in-depth interview guideline with seven main points was prepared and more detail discussions were conducted with the individuals spotted during preparation for the focus group discussions.

The general purpose and process of focus group discussion and why the participants were chosen were explained and in the meantime, the participants were told to think about what they feel about the challenges and opportunities of Gada system in peacebuilding in Borana Oromo community of southern Ethiopia. Generally, focus-group discussions were held in order to obtain qualitative data as well as to validate and probe crucial points of already obtained data. 
This method helped me to gather data on challenges and opportunities of Gada system in peacebuilding, and the way used to bring peace in the area and the feelings and attitudes of the community on peace, the role of the gada leaders in peace process, potential values according to Gada principle or elements in the community and on the challenges and peace scenario.

\subsubsection{Document Analysis}

In order to fill the gap, which might be created by collecting the data from the respondents, the researcher searched for the documents from the local offices of national regional state. In this case, the researcher attempted to find the official graphs and some of the written documents. In order to cross check the data obtained through interviews and focus group discussions, the researcher examined the available documents from the concerned body.

Different books, articles, journals, dissertation and theses published and unpublished; and local, national and international documents were used for this purpose. The information obtained from document analysis has been employed to cross-check the data obtained through interviews and focus group discussions. Besides, informal conversation and personal experience and observation were employed to aid to understand and interpret the data obtained from the field.

\section{Results of the Study}

\subsection{Roles of Gada System in Peace Building}

According to one of my informants, gada system is system that transfers power peacefully to next abba gada which is called balli transfer among Borana Oromo community ${ }^{1}$. My informant said in the process balli transfer, the incoming groups go to the camps of the outgoing groups early in the morning before daybreak on horseback. After transmitting power, the outgoing Abba Gada delivers his descendant serious advices about leadership, blesses his successor to exceed and information about gadoma. The transmission of power is not only for political benefits but also for socio-economic transformation. The process of balli transfers is notable by community around them. People like peaceful transfer of power and congratulate both parties at their respective locations. The person going to be a leader observes many power transfers and learns about it since childhood and it is difficult to get a leader who refuses to give power when his term is over. During transference of power abba gada who gives balli blesses abba gada who receives power saying we will work together and live together peacefully, God may bless your clan and Oromo during your administration, succeed in your administration, may your periods be the time of peace, cattle reproduction, freedom, and rain.

The above statement implies that the nature of gada system practiced among Borana Oromo community is preaches peace within the group and the country in general. For instance, the

1 Personal interview with one of officilals at Yabello town. power transference of outgoing and incoming abba gada is peaceful which can easily be expressed to contribute to wellbeing and peaceful coexistence and it can reduce the cause of violent conflict. Because the major source of conflict or protest in our country is competition for power on which party has to govern the country. So, where there is gada system, there is peaceful balli transfer which can play a great role in maintaining peace and stability in Oromia regional state and Ethiopian country in general. If we are working to avoid cause of conflict we are engaging in peacemaking activities. Therefore, gada principles and practices of peaceful power transmission can minimize the risk of competing for power because many causes of the conflict in the region were to get political power within the country. For this gada system can be a model that guides the leaders to exercise their power within the fixed period of time. If this culture is introduced within the country, dispute which demands equal representation in political activities and other politics related instability can be minimized.

As my informant explained to me the abba gadas and Borana Oromo community elder has a role advising the young generation not to violently ask their questions ${ }^{2}$. They say stop destructing someone's property because it is your property. They also guide the qeerro's (Oromo Youth) to be abided by the rules and regulation of gada which is the base of the democracy. Then, continued saying the culture of Borana Oromo community is not culture of conflict but it is full of peace for every society. For Borana community, culture means their lives. So, one who breaks the culture of Borana community is equivalent with denying the very existence of the Borana communities. My respondent said also our youth receives the message of elders and abba gadas' but fail to get officials who pay attention to their questions. He clarified this; government officials at different level should listen to the qeerro. This could be a cause for political crisis happening in our country. Elder of Borana Oromo I have interviewed has a knowledge of advising the youngster to be governed by the law of gada. The role played by elders and abba gada was not simple. For instance, during the disagreement of youth at different parts of Borana, they met the community in cooperation with the officials of the zone to alert the gada values and principle that there is no value added by destructing governments properties rather it is the way deviating from our culture of peace which in turn affect negatively our gada system.

According to the Borana FGD discussants ${ }^{3}$, the Borana Oromo gada system provided leadership and rules and procedures which served Oromo society well, safeguarding their liberty against authoritarian rulers because it is machinery for democratic self-rule and enjoyment of maximum liberty for the people. They said institutions like adoption ('Moggaasaa'), conflict resolution ('Araara'), compensation ('Gumaa), Oromo religion ('Waaqeffannaa'), 'Irreecha', and Siinqee were make-up of Gada system. They

\footnotetext{
2 Personal interview with community elder at Haro Bake

3 Summary of group discussion with members of gada Hawwattu at Halona
} 
discussed that adoption (moggasa) is the major method through which the Borana Oromo used to include the members of other society to its nation. According to the principle of adoption the adopted individual or group have equal social, political and economic rights to the adopting group. So, according to my discussants it is the method of getting the citizenship of Oromo. They continued discussing saying adoption can be expressed in two cases i.e adoption by relatives and adoption by clan in which the former is method of including someone mostly an Oromo to one's family and the latter is the process of including non- Oromo to certain clans of Oromo. Therefore, adoption in general has a role to make interrelation of Oromo and non- Oromos' as well as strengthening the unity of Oromo society. They said this can have a role settling the conflict between or among Oromo society.

The above discussion with Members of gada Hawwatu tried to point out how gada principles or elements of gada system can build peace in Oromo society. Gada system aims at the restoration of order and harmony of the community (which does not necessarily mean the return to the status quo, but can also imply some sort of transition to new arrangements). Cooperation between conflict parties in the future has to be guaranteed which can be a base to build peace within Borana Oromo community.

As stated by participants from members of gada Hawwatu, reconciliation (araara) is necessary for the restoration of social harmony of the community in general and of social relationships between conflict parties in particular, and it is not least necessary for restoring good relations with the spirits of the ancestors and gods or god. Borana Oromo community are very responsive to their values and norms; in most parts of the country, particularly in rural areas, people obey with their customary leaders and elders over the formal or government-run systems such as the police and the court. The 'officials' of the gada institutions make decisions ranging from simple disputes to complex issues through the system of hierarchy. Issues were seen, discussed and decided according to their level of seriousness in the hierarchy of the gada institutions. Customary institutional arrangements can therefore enhance the role of communities in addressing their own problems by themselves rather than submitting, as passive objects, to the directions of a distant centralized authority. States for the most part have a limited capacity to enable such a degree of inclusive participation in the decision making processes.

My key informant from members of officials at Oromia culture and tourism bureau described about Oromo religion as follows;

The Oromo believe that Waaqa is creator of all things, source of order and justice, omnipotent, omniscient, omnipresent. Oromo believe that Waaqa put everything in order and if anybody breaks his order, it results in sin, which in turn leads to punishment. He added that the Oromo also believe that Waaqa could punish anyone who commits sin, because they consider him as the one who guards the truth. The punishment may be in the form of a bad harvest, disease, famine and other hazardous events. The relationship between Waaqaa and the Oromo is not only reflected through the belief system, but also through their social organization. Borana Oromo communities believe in the law of God which is the base for the morality and ethical behavior of a person or the group. If all community become ethical person and abided by the law of gada possibility of occurrence of complaint including any other conflict among and/ or between the societies reduced to least level. So, peace can be rebuilt among the societies of Borana Oromo community because they believe that doing bad thing towards others is considered as the deviant from the law of God which is sinful action.

According to the information obtained from officials ${ }^{4}$, a person commits cubbuu if he breaks a certain safuu (traditional and moral values of the society) such as killing another person, lying, cheating, robbing, disrespecting one's parents and elders, abandoning belief in Waaqa, abandoning one's culture and tradition, neglecting responsibility, and being ungrateful. Therefore, for him one who believes in waaqa (God) never participates in killing another person because they consider as it is sin action before God. He added performance of various rituals related to Waaqa, one of which is the Irreecha ritual. Large numbers of Borana Oromo community also take part in the Irreecha (thanksgiving) ritual by Lake Arsadi at Bishoftu town. However, today the majority of the Oromo are predominantly followers of Islam and Christianity but they have also retained much of their traditional beliefs such as belief in the God, which they refer to as Waaqa. This is because followers of another region i.e Christianity and Islam consider as if going to celebrate waaqa at water bodies is sin. As a result of expansion of different religion in the area, culture of Borana oromo community is failing in the practice of its originality. Religion has negative impacts on the development of gada system he added.

In addition to this informant from oromia culture and tourism bureau said that Irreecha is not always celebrated by bodies of water such as rivers, lakes, and springs. Irreecha can also be celebrated in front of one's house, in a compound, in the diinqaa (sleeping room), as well as on hilltops, mountains and other elevated grounds. Irreecha involves thanking Waaqa while carrying things which cannot be eaten or drunk. Participants always carry green grass and flowers ${ }^{5}$. My informant quoted genesis 1:1-2 of holly bible to clarify why Oromo celebrate at waters or lakes. This quotation says "In the beginning God created the heaven and the earth. And the earth was without form, and void; and darkness was up on the face of the deep. And the spirit of God moved upon the face of the waters". So, Oromo celebrate at Lake Arsadi because they believe the spirits of God is moved on the face lake he said. However, Oromo never pray for the lake and water but to the creator of that water and lake.

My informant describes the siinqee as a "women's weapon" representing the respect and power that a married woman has. My informant explained that "If a woman has a siinqee, she

4 Personal interview with officials at Borana culture and tourism office 5 Personal interview with officials at Oromia culture and tourism office 
has to be respected, nobody should contest with her". Here, it is very important to note that siinqee is appropriate to women who have been married in accordance with the gada system. If marriage doesn't concluded by the rules and regulations of gada system, the women doesn't set respect equal as the one who hold siinqee like in the case of marriage by force (buttaa) ${ }^{6}$. It is an organizations accepted by the Gada which are solely run by women. Women could not be abba gada rather she can be Haadha gada (mother of gada). Because the informant said that the wife of abba gada has recognition equal to him. The culture of Borana Oromo community enforces Abba gada to have a wife.

\subsection{Gada as a System of Peace}

According to my discussants from member of gada Arbora, the Borana accept the existence of individuals who are wise, experienced and have familiarized themselves with the Aada-seera Borana. It is therefore, as the discussant said, that these individuals who acquire legitimate power as law enforcers all over Borana Socioeconomic organization maintain the nagaa Borana (peace of Borana). The Borana assume that those individuals, who are entitled leaders of gada system, are impartial in making moral decisions and judgments, out lining criteria and distinguish right from wrong and bad from good or truth from false. Thus, it is morally accepted by Borana Oromo that they are given a moral and legitimate power or moral supremacy to handle conflicts in all social units. Borana community is peace loving individuals who abided by the culture and law of gada system. Borana law never allows the violent dispute that directed to destruction of resources and lives of the people.

Gada system has set of laws called the aadaa and seera ${ }^{7}$ in which it is forbidden to deny someone access to water or to ask payment for it. The aadaa and seera (Borana laws) are rehearsed at a meeting that is held every eight years in Borana. This meeting is known as Gumii Gaayoo (meeting of the multitude). The underlying principle is that though Gada rules, fair treatment of an individual can be maintained so that conflicts can be avoided and peace is sustained. As a result, social relations of Borana society are based on Nagaa Borana (the peace of the Borana) can be sustained. Borana Oromo community defines peace not as the absence of war but as appropriate relationship within the localities and with God, Waaqa. The relationship between different clans, villages and households or any other social group is based on cooperation and mutual respect.

Borana elders are famous in blessing and praying for waaqa to bring peace and unity among themselves and all other ethnicity living in the country ${ }^{8}$. Most of the time elders blessing stress on the need of searching for sustainable peace and a way in which peace can be promoted. This is through strengthening the unity among Borana Oromo community. The message is clear that if Oromo society in general and

6 Personal interview with community elder at Haro Bake of Arero.

7 Summary of FGD with members of gada Arbora

8 Interview with Borana oromo elder at Dubluq town
Borana Oromo community in particular live together the anti-peace forces never enter into the Oromo political spheres and people live in peace governed by the gada principles and values. The disunity among Oromo society was mainly initiated by the politicians to take Oromo land. If Oromo divide themselves based on different characteristics such as religion, zones, clan etc and fail to remain together, other forces may enter into cultures and politics of Oromo to use for its political agenda. However, issue of peace should not be for the sake of politician's alone rather all Oromo people has a role to maintain peace.

The gada principles and rules are subjected to flexibility that is it can be modified by gada leaders and council at general assembly once per year. The following is the description given by my informant about gada law;

"The laws of gada system is always adapt to amendment". It is a system of self- adjustment in which each and every member of community participate in Gumi Gayyoo (general assembly) to declare a new law according to their interests. In gada system the law is made by general assembly is a supreme law. No one is above the law in gada system, even if abba gada or the leader of gada deviate from law the action is known as seera cabsaa (the act of breaking of law) then he is accused and leads to impeachment (buqqisuu). After the abba gada the head of gada executive branch overthrown by committing seera cabsaa (doing an act of breaking law) during his 8 years, power transferred to one of the member of Abba gada's. For Oromo law is above everything that promotes peaceful coexistence of the community. So, in general he said Borana Oromo communities are always abided by the rules and regulations of gada system. Everybody fears laws of gada. Then if all peoples are governed by law there is peace in community. To contrary if peoples can't fear the law of gada and believe as if they are above the law, social disturbance will happen easily. Then he said if communities fail to be governed law no one can fear each other including government".

According to an interview I had with members of gada council of Arbora, they explained that Oromo ask his right according to gada principles and law of a country. So, they said the concerned body has to give due concern for this questions. Oromo ask a question of human and democratic right by law. Because of this we can say there is democratic system among Borana Oromo community. If we don't ask for our right according to gada laws and regulations we may violate the right of others which is sign of selfishness. Therefore, Borana Oromo communities have to ask their rights in a peaceful manner in which their question doesn't affect the rights of others because if you respect others, others will respect you ${ }^{10}$.

The above statement implies that while you are asking for your rights you have to respect the rights of others groups as well. If not, God will ask you one day. Therefore, the chaffe or gumi gayyoo obliges each and every community not to

9 personal in-depth interviewee with members of gada councils (Adula) at Arero 10 A summary of focus group discussion with members of gada Arbora 
destroy the properties of others because gada principle considers properties of others as it is yours' also. Damaging someone's property means damaging your property. As of Oromo tradition one who did bad thing towards others commits against the law of gada. If you do bad thing toward others God will ask you if not you, your children will be penalized by the wrong you have done towards others. The gada rules consider each nation nationalities and peoples are ours. If you want to ignore them as part of Ethiopian and want to make an independent Oromia, this is against the law of gada. Because, let alone human beings, wild animals doesn't live separately. Leave about allowing non Oromo's to be separated from us, gada system allows Guddifacha (adoption) the process by which non Oromo's are adapting to the culture of Oromo community and living with them in peace.

Abba gada should have the ability to manage his family and Borana people at large. He should be fair in his decision. Again, people expect peace in Borana during the eight years of gadoma of an Abba gadaa man. The statement of one of my interviewee ${ }^{11}$ reflects these assumptions and expectations saying Abba Gadaa should promote peace where he lives in a community by just seeing the problems of his community and lead like God. His has to be impartial while taking decisions in order not to make a discrimination of some clan by advancing the interest of other groups or clan. Abba gada has to treat all Borana people equally because he belongs to all clans of Borana. This implies that any Abba gada of Borana have a responsibility to be exemplary for its society in making and building peace in the area they are living not only for his clan but also for all communities living in the region.

\subsection{Challenges and Opportunities of Borana Oromo Community's Gada System in Peace Building}

\subsubsection{Challenges of Gada System in Peace Building}

\section{(i). Politicization of Gada Leaders}

One of my informants described that Abba Gada men and the government became working collectively by interfering in their daily activities. This feared us because no one can transfer the basic knowledge about the culture of Borana because abba gadas' are started ignoring the culture. As a principle government and culture (gada system for Borana) are separate entity and do not mix each other. Abba gada are supposed to preserve the culture but they are failing to this because of the interference politics with culture. Gada leaders these days are influenced by the government policies and programs. He added they intervene in the political affairs of the country by declining the values and norms of the community they represented. He again said since most of gada leaders are illiterate they are simply convinced by any government body to do whatever they are told to do so. $\mathrm{He}$ said also because of this the gada leaders and councils were following the politics of government at the expense of the original culture of Borana Oromo people. Some gada leaders interfered in the political activities of the country to get some benefits. These benefits might be finance, budget, and acceptance by officials. As a result gada system is failing to operate according to its original form he said. ${ }^{12}$ "

The informant forwarded the message that Borana Oromo gada leaders have a problem of politicization which can influence the gada system not to be functioning in well manner. According to gada principles every gada leaders and members of gada council has to be free from the influence of politics of the country and has to serve the community in accordance with norms, cultures, and values of their lives as neutral person in between the government and the people.

On the other hand, there is external force that can influence the gada system not to function in a well manner. For instance according to informants, security force is becoming a threat to the well-functioning of gada system. He referred the case of 2016, Irrecha massacre as an example to explain how police force can influence the system. He said that the role of police force during crisis is important. However, since Oromo people consider the police for as the agent of government whom they are protesting against it, they have to be refraining from cultural festival of the community in general. The intervention of security force in cultural activities of Oromo community made the issue worse than peaceful protest before that time. The increased government involvement and increased expressions of resistance to government policies are visible in the area. The existence of security and surveillance, in a current in the place of festival is increasing. This is after the relationship between the EPRDF government and the Oromo population has weakened. We never want the intervention of security forces to the culture of the community. The government's intention to make peace at Ireecha festival by sending the security force was taken negatively by attendants of festival. What Oromo people wanted was to keep peace by themselves without government bodies' interference because gada system itself is the system of peace. The governments' plan to make peace during festival became the source of conflict between Oromo people and the government. This brought the death of many innocent attendees of Irrecha festival in 2016. Expression of Oromo culture and heritage have been interpreted as manifestations of dissent, and the government has also shown signs of fearing cultural expression as a potential catalyst for opposition to the government. Oromo singers, writers and poets have been arrested for allegedly criticizing the government and/or inciting people through their work. People wearing traditional Oromo clothing have been arrested at Oromo traditional festivals. Therefore, governments plan of intervention into traditional culture of Oromo society i.e Irrecha festival was misunderstood by youth. The youth perceives as police force want to detain them, but the intention of government was simply fear that the other organ may use Oromo Youth as catalyst of anti-peace forces during cultural expressions at Hora Arsadi.

12 Interview with community elder of Dubluq area 


\section{(ii). Lack of Budget of Gada Institution}

According to my informant, gada leaders are challenged by lack of budget ${ }^{13}$. It is obvious that in Oromo culture Abba Gadas do not collect tax from society as government system however, peoples provide him with necessary materials like food and drinks. Know the Gada leaders have no any budget as institution. Peoples are not helping them as traditionally learned. Gadaa leaders are expecting all things from government pocket even if to move from place to place in order to participate in Gadaa activities, like conflict resolution, rituals and to partake in any societal issue. Great effort is expected from concerned bodies to make independent Gada institution economically. Government has to support the institution since it is believed that Gada could bring peace, development and prosperity in this country.

\section{(iii). Low Level of Gada Knowledge}

The third challenge is low level of knowledge (lack of awareness) about gada system by new generations. It can take long time even up to a century because; current generations have no experience of Gada. Additionally, current generations are moving by push of globalization. They didn't want to give ear to elders who intend to teach them about gada system. Even though Knowledge of gada is transferring from father to child or from one generation to the next some Oromo groups such as Guji, Borana and some parts of shawa, the young generations are not willing to learn from abba gadas' and elders because, the young generations are influenced by the establishment of new technologies which has direct or indirect impact on the practice of gada system. Therefore, this is great obstacle to the sustainability of the system. However, teaching the society by different media is important. In addition to this the families have to grow their children according to gada system.

My discussants said even though Borana Oromo community is better in practicing gada system, there are places in which gada never works in Oromia regional state. This in turn challenged the Borana Oromo community not to live in peace because people residing in different parts of the region are sharing information about what is happening in the country. For instance they said if protest violently happened today in one areas of Oromia, all people living in the country can know it easily using new technology such as mobile phone, internet, Facebook and etc. After being aware of the cause and consequences as well as the main questions they raised I different parts of the region, the Borana Oromo community especially youth also starts to protest sharing the problems come across by other Oromo community. This can be through use of social Medias which can be expressed in protest songs ${ }^{14}$

\section{(iv). Religion Impacts}

Informants ${ }^{15}$ have expressed their fear that the expansion of other religions in their community, undemocratic practices in

13 Personal interview with official at Yabello town

14 Focus group discussion at Arbora town of Borana Zone

15 Key informant interview with officials of Borana culture and tourism bereau some parties, lobbying, few procedural irregularities and permanent settlement are affecting the practice of gada system in their community. They considered as sin some rituals practiced in gada system. My informants confirmed that majority of the study area peoples are forgetting waaqeffannaa religion by influence of Islam and Christianity religion. They are adopting the external religion imposed on them. The conservative followers of different religion in Borana Oromo community consider as going celebrating Irrecha festival is sin. For instance, qaalluu institution is the center of Oromo indigenous religion. It is this strong value attached to the qaalluu institution that makes peace making more lasting and binding. However, they said followers of another religion considers as taking a case to qaalluu institution is a sin. This made the institution not to practice among Borana Oromo community.

With regard to this, my interviewee said that the emergence of modern religion such as Islam and Protestantism in our country is undermining the Borana culture ${ }^{16} \mathrm{He}$ added Within the System waaqeffannaa (Oromo religion) is solely religion among Oromo people. For instance he said a thanks-giving ceremony known as Irrecha nationally celebrated at Lake Arsadi. The Gada System has developed through the cumulative experiences gained from practices and lessons of many generations of Oromo Nation. This was affected by some followers of protestant and Islam in some cases because they preach as going to Irrecha celebration is sinful.

From the above statement of my informant I can say that the recent religion introduced in Ethiopia by modernization process can have direct or indirect impact up on the practice of gada system which might also decline of Oromo culture. In general where the gada system is fully practiced there is peaceful coexistence of the people and democracy can be grow well because it encompasses many basic features that international and national protocols and conventions have included in their main parts.

\subsubsection{Opportunities of Gada System in Peace Building}

My discussants reported this gada institution has much strength in peace building. Frist, the system allows gada leaders to be trusted by the community which is a critical commodity for the legitimacy of any governance arrangement ${ }^{17}$. The system is important to build peace at the local level because it has social ties arrangement which makes gada leaders so trustable by the community. In addition the culture Borana Oromo community also obliges the community to be loyal to the orders of elders. This means that Abba gada and members of gada council are closest to the community to listen problems and demand of the people in general. So, they are trusted by the community and might serve as the channel of communication between the people and the government. Gada leaders can do the work of messenger for the people they represent.

Informant added that gada system is a form of democratic governance that has invaluable contribution in today's politics.

16 One of my informant at office of tourism and culture of oromia

17 Key informant interview at yabello town 
When all community and government abided by gada principle it is a way of avoiding the sources of disagreement and ways of holding mutual understanding of all parties which is win-win frame reference of conflict transformation. As informants described, the case of Oromo protest can be managed if government hears what the community are wanting or demanding and take possible answers for their question. Because, the youth are protesting not because of they have negative attitude towards leaders or hating the government but lack of good governance raised by many protestors. In this case, government bodies have to approaches to them and identify what they really want. For him it is a question of democratic governance that tolerates the interest of diverse nation of the country. Gada is a complete system and fully characterized by democratic values that undergone centuries without any internally disruptive actions and managed to get here especially among Borana. So, every Borana community including gada leaders have a responsibility to respect the rule of law.

According to informants gada principle has also a value of transferring power within a fixed term of office. He said of the Abba Gada is limited to a single term office for eight years. This fixed term office of gada leaders is practicing among Borana Oromo community which can be taken as a base of avoiding a cause of source of conflict. Most African states engage in violent conflict or protest to take power. But, if used gada system, things that can be considered the cause of protest can be minimized because power is transferring peacefully to next incoming abba gada. Every Gadaa leaders remain in office for a formal eight years after which they have to hand over to the incoming Gadaa officials through a formal handing over ritual ceremony. This principle again fosters democratic system to function properly. He continued power is sensitive area of conflict. Power is desirable by every community. If power related protest is managed then peace can built and any violent protest can be avoided ${ }^{18}$. So, having a single and fixed term office of gada leaders can avoid root causes of protest. Peaceful transmission of power qualifies gada system.

In general, gada system promotes the principle of modern democracies principle which is established based on the interest of the people. For Borana Oromo community, if the system or institution that promotes their interest and demand is established implemented well, any source of conflict including protest can be minimized

\section{Conclusion and Recommendations}

The study reveals that challenges and opportunities of gada system in peace building in Borana Oromo community with respect to current protest. In Gada system conflict including any kind of protest is transformed by performing gada principles and values such as limiting power duration, avoiding power monopolization, balancing institutional power occupation, differentiating or separating institutional roles,

18 Personal interview with community elder at Dubluq town putting collective accountability on political and institutional leaders of Gada. If the above mentioned principles and values of gada system are implemented by both government and society in general, any means of protest can be minimized. The gada system by itself involves a system of avoiding the cause of conflicts through norms and institutional formulation. Gada approach is based on a system of promoting an institutional problem solving through various systems of cooperation between different institutions within a single Gada institution (Geremew, 2012)

Based on the findings of the study the researcher forwards the following recommendations to be implemented by the concerned bodies.

The finding of the current work indicated that there are challenges to the practice of the Gada system in peacebuilding. The politicization of gada leaders, expansion of other religions such as Christianity and Islam, lack of budget for gada institution, low knowledge of gada system among current generations due to external interferences by modernization and globalization are affecting the good practices in the gada system in peacebuilding. Therefore, there should be mechanisms of adaptation to these challenges. The gada leaders should have to be governed by the gada values and principles without interfering into the political activities. The intervention of Abba gada and council of elders in political affairs has to be minimized in order to preserve the culture of the Borana Oromo community which is based on the gada system of restoring peace. In addition, the government has to minimize the level of interference in the cultural affairs of the community. Meaning the intervention of government in cultural practices of the community should be limited to maintain peace. This is because as the level of interaction increases the community loses their original practice of gada system. Therefore, the independent i.e free from government influences Gada institution has to be established.

The finding reveals that the current generations are moving by the push of globalization at the expense of their culture and system. Even though Knowledge of gada is transferring from father to child or from one generation to the next among Borana Oromo community, the young generations are not willing to learn from Abba gadas' and elders because, the young generations are influenced by the establishment of new technologies which has direct or indirect impact on the practice of gada system. Therefore, I recommend that the community especially new generations (youth) should have to have written documents of their culture and the system so that they can maintain them. I addition, Government should incorporate programs relating to traditional cultures, heritage and folklore in education curriculum at all levels and government should provide training in the use of information communication technology for documentation, digitization, and preservation of cultural heritage.

The finding of the study also indicated that gada institution has a financial constraint. Gada leaders are expecting all things from government pocket even if to move from place to place in order to participate in Gada activities, like conflict resolution, peacemaking/ building, rituals and to participate in 
any societal issues. Therefore, government as well local peoples have to assist the Gada officials financially and provide them with necessary logistics.

The finding reveals also Gada system has an opportunity of making peace by its principles and practices or values in the community. Practices of consensus-based participatory public discussions can easily be found amongst indigenous communities in Ethiopia. The Gada system was found to have a greater potential of protecting a constitution than the current Ethiopian federal system could ever offer (Sirna, 2015). The Gada system is the administrative system that enables the public to resolve all social problems peacefully and sustainably. The Gada system is a system that strengthens social fabric and moral values thereby guaranteeing the protection of property. In Gada system conflict including any kind of protest is transformed by limiting power duration, avoiding power monopolization, balancing institutional power occupation, differentiating or separating institutional roles, putting collective accountability on political and institutional leaders of Gada.

\section{References}

[1] Allo, A. (2017). Protests, Terrorism, and Development: On Ethiopia' s Perpetual State of Emergency. Yale Human Rights and Development Journal: Vol. 19: Iss. 1, Article 4.

[2] Asafa, J. (2005). Oromia and Ethiopia: State formation and ethnonational conflict, 1868-2004.

[3] Assefa, G., \& Pankhurst, A. (2016). Grass-roots justice in Ethiopia: The contribution of customary dispute resolution. Centre français des études éthiopiennes.

[4] Ayana, D. (2010). From geographic skirt to geographic drift: the oromo population movement of the sixteenth century, Journal of Oromo studies: vol. 17, No. 2.

[5] Ayele, Y. T. (2016). The Discursive Construction of Identity: The Case of Oromo in Ethiopia (unpublished master's thesis). Norwegian University of Life Sciences, Oslo, Norway.

[6] Bahru, Z., 2014. The quest for Socialist Utopia: The Ethiopian student movement c. 1960-1974. s. 1. James Currey.

[7] Baissa, L., 1994. Gada Values: The building blocks of democratic Oromo polity. he Journal of Oromo Studies, 1 (2), pp. 47-53.

[8] Bassi. M. (1996). Power's Ambiguity or the Political Significance of Gadaa: Being and Becoming Oromo, Historical and Anthropological Enquiries.

[9] Brown, T. M. (2017). From participation to protest: The link between protest and participation. Stellenbosch University.

[10] Conteh-morgan, E. (2004). Peace-building and Human Security: A Constructivist Perspective, IPSHU English Research Report Series No. 19.

[11] Conteh-morgan (2005). Peacebuilding and human security: a constructivist perspective. International Journal of Peace Studies, 69-86.

[12] Cravo, T. A. (2017). Peacebuilding: Assumptions, Practices and Critiques: journal of International Relations vol, 8. no. 1.

[13] Cress well, J. W. (1994). Research Design: Qualitative and Quantitative Approaches, Sage.

[14] Fiseha, A. (2006). Theory versus practice in the implementation of Ethiopia's ethnic federalism. Ethnic federalism. The Ethiopian experience in comparative perspective, 131-164.

[15] Galtung, J. (1967). Theories of peace: A synthetic approach to peace thinking. International Peace Research Institute, Oslo, 2 (6).

[16] Gebissa, E. (2018). The Oromo and the Christian Kingdom of Ethiopia 1300-1700, 16 (2), 143-148.

[17] Geremew. N. (2012). Gada theory and practices: Gada institution, political process and system of conflict resolution. Oslo, Norway.

[18] Gonfa. I. (2014). Customary conflict resolution among the Haro Limmu oromo of northwest Wallaga: the case of Qaalluu institution. Masters thesis. Addis ababa university.

[19] Gudina, M. (2006). Contradictory interpretations of Ethiopian history: The need for a new consensus. Ethnic federalism: The Ethiopian experience in comparative perspective, 119-30.

[20] Gulliver, P. H. (1979). Disputes and Negotiations: A Cross Cultural Perspective, Studies in Law and Social Control. New York.

[21] Gutema, S. E. (2017). Harnessing Gadaa System as a Black Covenant in Modern Constitutional Administration: Appraisal of Prospects and Challenges. Sociology and Anthropology, 5 (1), 52-62.

[22] Habtamu. D. (2017). Indigenous knowledge and practices of leader and leadership development in the gada system of Borana Oromo community of Ethiopia: Doctoral dissertation of philosophy in social pyschology. AAU.

[23] Haider, H. (2009). Community-based approaches to peacebuilding in conflict-affected and fragile contexts.

[24] Jalata, A. (2013). Colonial terrorism, global capitalism and African underdevelopment: 500 years of crimes against African peoples. Journal of Pan African Studies, 5 (9), 1-42.

[25] Karbo, T. (2008). Peace-building in Africa. Peace and conflict in Africa, 113-32.

[26] Lederach, J. P. (1997). Sustainable reconciliation in divided societies. Washington, DC: USIP.

[27] Asmarom, L. (2000). Oromo Democracy: an indigenous African political system. Free Press.

[28] Loveness, N., \& Mathew, S. (2017). The role of indigenous knowledge systems in peace building: a case of Umguza district, Zimbabwe. International journal of politics and good governance, 8 (8.1).

[29] Mamo, D. F. (2017). Indigenous Mechanisms as a Foundation for AfSol Comprehension: Lessons from Gadaa System of the Oromo Nation in Ethiopia. Sociology and Anthropology, 5 (5), 379-387.

[30] Murithi, T. (2008). African indigenous and endogenous approaches to peace and conflict resolution. Peace and conflict in Africa, 16-30. 
[31] Opride.

(2016).

https://www.opride.com/2016/09/02/oromo-abba-gadaa-leader s-call-withdrawal-federal-army-release-political-prisoners/

[32] Opride (2018). Ethiopia: Oromia state rocked by protests and killings amid a 3-day market boycott. Retrieved from https://www.opride.com/2018/02/13/ethiopia-oromia-state-roc ked-protests-killings-amid-3-day-market-boycott/

[33] Paffenholz, T. (2014). International peacebuilding goes local: analysing Lederach's conflict transformation theory and its ambivalent encounter with 20 years of practice, 2 (1), 11-27.

[34] Zelalem Sirna. T. (2012). Ethiopia: when the Gadaa democracy rules in a federal state. Bridging indigenous institutions of governance to modern democracy (Master's thesis, Universitetet i Tromsø).

[35] Simpson, A. (2014). Community. In The Brand Strategist's Guide to Desire (pp. 19-49). Palgrave Macmillan, London.

[36] Tesema, T. (2004). The Place of the Oromo in Ethiopian History: 2003 OSA Conference Keynote Address. Journal of Oromo Studies, 11 (1-2), 1-11.
[37] Wemlinger, C. R. (2008). Identity in Ethiopia: The Oromo from the 16th to the 19th Century (Doctoral dissertation, Washington State University).

[38] Zola. K. (2016). Ethiopian Human Rights Project: Oromo Protests, 100 Days of Public Protests, Addis Ababa.

[39] Degefa, A. (2015). Justice that Heals and Restores: The Potential of Embracing Borana Oromo Indigenous Justice System alongside the Ethiopian Formal Criminal Justice System, Doctor dissertation of Philosophy Degree in Social Work and Social Development, AAU.

[40] Tenna. D. (2008). The concept of peace in the Oromo Gadaa System: Its mechanisms and moral dimension. Journal of Oromo Studies, 15 (1), 139-179.

[41] Boege, V. (2011). Potential and limits of traditional approaches in peace building. Berghof Handbook II: Advancing Conflict Transformation, 431-457.

[42] Deutsch, M., Coleman, P. T., \& Marcus, E. (2011). The handbook of conflict resolution: Theory and practice. John Wiley \& Sons. 